\title{
PRIVATE REFORM OF TORT-LAW DOGMA: MARKET OPPORTUNITIES AND LEGAL OBSTACLES
}

\author{
Clark C. Havighurst*
}

\section{INTRODUCTION}

At this point, the focus of the symposium shifts away from possible legislative reforms of malpractice law in order to consider whether some relief from malpractice problems might be obtainable through private action-that is, through private contracts altering the responsibilities of health care providers and the legal rights of patients. ${ }^{1}$ The first thesis to be presented here, in opening this subject, is that the idea of private reform in the area of medical malpractice squares nicely both with recent developments in national health policy and with recent changes in the health care industry itself. It will also be contended that the legal system, to the extent that it is unreceptive to contractual variations of its rules governing medical accidents, is out of touch with recent developments and needs to have its premises reexamined. The observations here support the view that tort law must recede from a dogmatic regulatory role in which it alone specifies rights arising out of the provider/patient relationship and should recognize that private agreements altering its prescriptions may benefit everyone appropriately concernedeveryone, that is, except malpractice lawyers.

An examination of the implications of recent health sector developments for malpractice reform should be helpful to several audiences. Those who focus their attention primarily on liability issues are apt to be only generally aware of what is happening in health policy and in the health care marketplace

\footnotetext{
Copyright (c) 1986 by Law and Contemporary Problems

- William Neal Reynolds Professor of Law and Director of the Program on Legal Issues in Health Care, Duke University.

1. The notion that patients' tort rights might be varied by contract has been advanced in other places. E.g., P. Danzon, Medical Malpractice: Theory, Evidence, and Public Policy 209-13 (1985); Bovbjerg, The Medical Malpractice Standard of Care: HMOs and Customary Practice, 1975 DuKE L.J. 1375; Epstein, Medical Malpractice: The Case for Contract, Am. B. Found. Research J. 87 (1976); Havighurst, Decentralizing Decision Making: Private Contract Versus Professional Norms [hereinafter cited as Havighurst, Decentralizing Decision Making], in Market Reforms in Health Care 22 (J. Meyer ed. 1983) [hereinafter cited as MARKET REForms]; Havighurst, Reforming Malpractice Law Through Consumer Choice, Health AfF., Winter 1984, at 63; O'Connell, An Alternative to Abandoning Tort Liability: Elective No-Fault Insurance for Many Kinds of Injuries, 60 MINN. L. REv. 501 (1976) [hereinafter cited as O'Connell, An Alternative]; O'Connell, No-Fault Liability by Contract for Doctors, Manufacturers, Retailers and Others, 1975 Ins. L.J. 531 ; Stevens, Medical Malpractice: Some Implications of Contract and Arbitration in HMOs, in Law and Ethics in Health Care 265 (J. McKinlay ed. 1982). The idea remains largely academic, however, in part because of anticipated judicial hostility.
} 
and may not fully appreciate the connection between those developments and what is happening, or might happen, in the tort arena. Similarly, those concerned with overall health policy may view the malpractice problem as a tangential matter falling into a separate policy compartment-even though this body of law defines important elements of the provider/patient relationship and generates incentives powerfully influencing provider behavior. Finally, employers, insurers, and other intermediaries who purchase health care as agents for consumers may fail to see how malpractice law affects, perhaps adversely, the cost and quality of the services they are buying.

Even if some of these various observers do appreciate that malpractice law affects larger interests, they are still likely to view malpractice issues as addressable only through the courts or through specialized political processes engaging rather different protagonists than are usually involved in making health policy. Yet malpractice issues may be too important to be resolved definitively by judges or in legislative showdowns between organized medicine and organized trial lawyers. It is at least possible that the same public policies and private initiatives that are currently transforming health care financing and delivery will in time, if given a chance, bring about meaningful and desirable reforms in the way society allocates the risk of iatrogenic injury. ${ }^{2}$ Those private interests that are currently engaged in revolutionizing the health services industry should certainly not neglect to explore opportunities for redefining legal rights and remedies in the interest of improving the climate and efficiency of medical practice and giving consumers better value for their money.

In addition to demonstrating that the new health care marketplace offers unprecedented opportunities for reforming malpractice rules through consumer choice, this article examines the legal obstacles in this path to reform. Not the least of these obstacles is the natural conservatism of lawyers who, in counselling health care providers, tend immediately to discount the possibility that tort rights might be effectively altered by private agreement. Such caution is perhaps warranted in a legal system that is generally distrustful of private contract as a vehicle for defining consumers' rights. ${ }^{3}$ Nevertheless, it will be shown here that there is no reason automatically to presume judicial hostility to all contracts altering malpractice liability. Indeed, with the emergence of a competitive market for health services and new opportunities for informed purchasing by consumers and their agents, courts may now have even less reason to view contractual modifications of tort rights skeptically. One purpose of this article is to encourage creative lawyering in the structuring and defense of such agreements.

2. Reasons for not being unduly sanguine about this prospect are given in note 91 , infira.

3. See infra note 60 and accompanying text. 


\section{The Changing Environment in Which Health Care Is BOUGHT AND SOLD}

The suggestion that the legal remedies of patients injured in the course of medical treatment should be alterable by private contract and not exclusively by public action will seem more sensible with an appreciation of how the health care industry and ways of thinking about health care itself have changed in recent years. Old assumptions, which contemplated centralized decisionmaking on virtually all questions, are now rapidly giving way to the notion that consumer choice can reliably guide industry development and the allocation of resources to and within the health care sector. The discussion here reports briefly on how decisionmaking authority is shifting away from health care providers to consumers, how changing public policy has fostered this development, and how old conceptions of health care are being replaced by new ones. It will appear that consumers are increasingly in a position to negotiate with providers mutually advantageous relationships that feature, among other things, rights and responsibilities with respect to medical injuries that differ from those prescribed in the law of torts.

\section{A. From Monolithic "System" to Decentralized, Competitive "Industry"}

The changes that have overtaken the U.S. health care industry in the 1980 's are more revolutionary than is commonly appreciated. This period has seen the end of the long era during which health care was generally deemed to be a uniform product produced by a single, monolithic system dominated by the providers of care. ${ }^{4}$ The development most widely noted as undermining provider dominance is the increasing aggressiveness of large purchasers of services in demanding provider attention to their concerns about health care costs. ${ }^{5}$ Government and private purchasers of health care have now learned that their old, provider-approved practice of agreeing to reimburse virtually any cost that providers or patients elected to incur was an invitation to high prices and wasteful spending. As a result of the new attitudes and policies that these purchasers have adopted, consumers are now able to reject the dominant system's standardized product by choosing to receive care through innovative delivery mechanisms and under new financing arrangements. New payment methods are forcing many traditional fee-for-

4. The fullest description of the old provider-dominated system and how it came to be is given in P. Starr, The Social Transformation of American Medicine (1982). See also J. Berlant, Profession AND Monopoly 58-127, $177-308$ (1975); Clark, Why Does Health Care Regulation Fail?, 41 MD. L. REv. I, 4 (1981) (discussing "the deference that our legal system pays to the judgments of the medical profession"); Havighurst, The Doctors' Trust: Self-Regulation and the Law, HEALTH AFF., Fall 1983 , at 64 .

5. See, e.g., J. Goldsmith, Can Hospitals Survive?: The New Competitive Health Care Market (1981); Lewin \& Associates, Inc., Synthesis of Private. Sector Health Care Initiatives (March 1984) (report prepared for the Office of the Assistant Secretary for Planning and Evaluation, U.S. Department of Health and Human Services); Arnett, Cowell, Davidoff \& Freeland, Health Spending Trends in the 1980 's: Adjusting to Financial Incentives, Health Care Fin. Rev., Spring 1985, at 1. On the federal government's new aggressiveness as a payer, see infra text accompanying notes 10-11. 
service providers to adjust their practice styles and administrative methods, to submit to or institute controls on spending, to set competitive prices, and to accept prospectively determined payments for treating a given condition, a given patient, or a given population. As physicians and hospitals respond to new economic realities, hospital admissions are fewer, stays are shorter, and operating efficiencies are being achieved. ${ }^{6}$ In general, cost-conscious purchasing and provider competition are revealing that the standardized product produced by the old health care system was not necessarily the best value.

Several specific factors have contributed to strengthening the hands of cost-conscious parties on the demand side of the health care marketplace. Increases in the supply of both physician personnel and hospital facilities have intensified competition among providers, making them more responsive to purchasers' cost concerns. Aggressive application of the antitrust laws to the health care sector, which began only in the mid-1970's, now keeps providers from continuing to dictate-by boycotts and other collective means-the kinds of delivery and financing arrangements that can be employed. ${ }^{7}$ In particular, antitrust enforcement has assisted the growth of health maintenance organizations (HMO's), a development that was important not only in its own right but also because it enabled the private sector to recognize that delivery arrangements differing from those prescribed by professional custom were feasible and cost-effective and could be attractive to many consumers.

If one had to identify the crucial event in the awakening of the private sector to its cost containment responsibilities and opportunities, that event would have to be Congress's defeat in 1979 of the Carter Administration's proposals for hospital cost containment. That legislative action effectively signaled that the federal government was not, after all, going to assume ultimate responsibility for the nation's overall health care bill and that private purchasers of health care, instead of waiting for government to solve the problem, should look out for themselves. This message was immediately reinforced by new legislative proposals looking to stimulate competition and cost-conscious consumer choice in the health care sector, ${ }^{8}$ by favorable references to competition in the 1979 amendments to the federal health planning legislation, ${ }^{9}$ and by the election of a conservative president in $\mathbf{1 9 8 0}$.

6. See, e.g., Davis, Anderson, Renn, Rowland, Schramm \& Steinberg, Is Cost Containment Working?, HealTh AFF,, Fall 1985, at 81. As this study notes, there are numerous possible explanations for the trends discussed, but it is clear that something important has happened and coincides in time with substantial changes in purchasers' attitudes. Id. at 91 .

7. See, e.g., Havighurst, The Contributions of Antitrust Law to a Procompetitive Health Policy, in MARKET Reforms, supra note 1, at 295; Havighurst, Professional Restraints on Innovation in Health Care Financing. 1978 Duke L.J. 303 [hereinafter cited as Havighurst, Professional Restraints].

8. The sponsors of these bills included health policy experts from both parties. See, e.g., S. 1485, 96th Cong., 1st Sess. (1979) (Sen. Durenberger); S. 1590, 96th Cong., 1st Sess. (1979) (Sen. Schweiker); H.R. 7527, 96th Cong., 2d Sess. (1980) (Reps. Gephardt and Stockman); H.R. 7528, 96th Cong., 2d Sess. (1980) (Rep. Jones).

9. Pub. L. No. 96-79, § 103, 93 Stat. 592, 594-95 (1979) (codified at 42 U.S.C. $§ 300 k-2$ (1982)). 
Unlike the Carter Administration, the Reagan Administration emphasized that private health care costs were a private responsibility and addressed itself to controlling, not overall health care costs, but the costs of public programs alone. In pursuing this policy, Congress set for the private sector a particularly vivid example in prudent purchasing of health care by shifting the Medicare program from retrospective cost reimbursement to payment for specific treatments on the basis of uniform, prospectively determined prices. ${ }^{10}$ In addition, the federal government encouraged the states to bargain aggressively with providers in administering Medicaid. ${ }^{11}$ Once government removed itself as the party responsible for private health care costs, the stage was finally set for market forces to assert themselves, and they have begun to do so.

Although consumer ignorance had long been deemed to preclude a workably competitive market for health services, consumers of health care are encountering no appreciable difficulties in the emerging competitive environment because they have been able to rely upon sophisticated agents to bargain with providers on their behalf. Thus, employers and unions, representing consumers' interest in cost containment, ${ }^{12}$ have begun to demand lower-cost alternatives that do not sacrifice essential quality. Increasingly, employers are selecting from the larger universe of options a limited menu of health plans or providers from which the employees themselves can finally choose, partly on the basis of price. Organized health plans, such as HMO's and preferred provider organizations (PPO's), are increasing their market shares, in part because they serve the consumer as knowledgeable middlemen capable of selecting providers and obtaining their services on desirable terms and of overseeing their performance. Other institutions and middlemen, such as hospitals, are also serving consumer interests in selecting physicians and other inputs. ${ }^{13}$ Thus, consumers are increasingly finding themselves in a position to bargain confidently and effectively with providers. As a result, consumers' preferences and cost concerns are being transmitted more effectively than ever before to the supply side of the market.

There are numerous specific manifestations of consumers' new ability to command providers' respect for their preferences. HMO's are now growing impressively as a private alternative offered to workers by employers and to

10. See Social Security Amendments of 1983, Pub. L. No. 98-21, § 601, 97 Stat. 65, 149-63 (codified as amended in scattered sections of 42 U.S.C.) (amending title XVIII, $\$ 1886$ of the Social Security Act, which was added by the Tax Equity and Fiscal Responsibility Act of 1982, Pub. L. No. $97-248, \S 101(\mathrm{a})(1), 96$ Stat. 331, 331-36 (codified as amended in scattered sections of 42 U.S.C.)).

11. Omnibus Budget Reconciliation Act of 1981, Pub. L. No. 97-35, § 2175, 95 Stat. 357, 80911 (codified as amended in scattered sections of 42 U.S.C.); see Johns, Selective Contracting in California, HeALth AfF., Fall 1985, at 32.

12. Given a competitive labor market, employers will attempt to provide workers with attractive health care plans at a reasonable cost in forgone take-home pay. See infra text accompanying notes 73, $81-82$.

13. See, e.g., Havighurst, Doctors and Hospitals: An Antitrust Perspective on Traditional Relationships, 1984 DUKE L.J. $1071,1136,1160-62$. 
public beneficiaries under Medicare and state Medicaid programs. During the 1970 's, such private innovation as took place tended to concentrate excessively on HMO development and to ignore other possibilities, such as the use of provider participation agreements and the creation of PPO's. This occurred in part because the federal government had signaled its acceptance of HMO's clearly enough that it seemed unlikely to undercut them in new regulatory initiatives or in any program of national health insurance. After the watershed events of 1979, however, the PPO concept began to take hold. ${ }^{14}$ By permitting health insurers to discriminate for the first time in their treatment of providers on the basis of the prices they charge or the costs they incur, PPO mechanisms have forced traditional fee-for-service providers into unwonted price competition. For the first time, they can expect to be pressed for price discounts and to see patients seeking care where prices or costs are lower. Although many elements of the private sector have yet to rethink what they are doing and to reorganize themselves to meet the many challenges, the tools for effective private cost containment are now widely available.

The net effect of the various policy and market developments noted here has been to set in motion private innovation and competitive forces that are now rapidly transforming the health care sector from a provider-controlled monopoly, funded by a passive financing system, into a vital, cost-conscious, competitive industry. Although it took some time to get the first olive out of the bottle, the forces that have been unleashed are now proving powerful indeed. The revolution remains in many ways incomplete, however, in part because some in the private sector are still shrinking from hard choices in the belief that either government or the system itself will choose on their behalf; also, state regulation continues to obstruct effective competition and change in some respects and in some places. Nevertheless, the dominant trend is away from both the old acceptance of professional dictation and the flirtations with governmental controls that characterized the 1970's, and it seems almost certain that the locus of responsibility has permanently changed. Even a swing of the political pendulum in a more liberal direction, though increasing attention to solving the problems of the poor and uninsured, ${ }^{15}$ would be unlikely to reverse the decentralization of decisionmaking authority that has occurred.

\section{B. Fading Tenets of the Old Health Care}

Virtually the only reference in the current malpractice debate to recent developments in health care financing and delivery is the frequently voiced concern that new methods of purchasing and paying for health services could,

14. PPO's take many forms but generally represent groupings of lower-cost providers to whom insurers steer patients by offering more favorable coverage. The Medicare program has recently required physicians to elect whether to participate in the program and accept its allowances as payment in full. Deficit Reduction Act of 1984, Pub. L. No. 98-369, div. B, tit. III, 98 Stat. 494, 1061 (codified as amended in scattered sections of 42 U.S.C.). Previously, the program was wedded to the idea that patients' choice of physician should be virtually unlimited.

15. See infra text accompanying notes 35-36. 
by forcing providers to economize in patient care, give rise to more malpractice suits for departures from customary standards. ${ }^{16}$ This very real and worrisome possibility is, however, only a manifestation of the deeper conflict between current market and policy trends, on the one hand, and received doctrines of malpractice law, on the other. As payers increasingly bargain with providers and as consumers increasingly use price as one criterion for their choice of care, it is becoming more and more difficult to defend the law's assumption that there is a single correct standard of medical care to which providers should be held in virtually all circumstances. ${ }^{17}$ Indeed, if some consumers are demanding economy, a strong argument can be made for allowing a provider's legal obligations to vary so that a less costly product can be delivered in response to that demand. Thus, it is possible to hear complaints about the inflexibility of malpractice rules in a market increasingly demanding cost containment as being essentially pleas for the reintroduction in health care of the free market notion that you get what you pay for.

The suggestion that consumer preferences, as revealed in market transactions, may legitimately affect the quantity and quality of services produced by health care providers is essentially the same notion that has appeared in national health policy and that is beginning to assert itself in the health care marketplace. Although it is generally accepted elsewhere in the economy that a buyer's willingness to pay should determine the nature of the goods and services he receives, this is a revolutionary idea in the health care field. Specifically, it is at odds with the hitherto fundamental tenet that patients are entitled to receive from health care providers not what they pay for, but what they need-not what they demand, but what doctors believe they should have. ${ }^{18}$ This idea has been closely related in turn to the myth that, as a technical matter, there exists one right way, discoverable in the collective wisdom of the medical profession, to treat each medical problem. ${ }^{19}$ A third variation on this same general theme has been the notion that the same standard of medical care should be available to all Americans regardless of their ability (as distinct from their willingness) to pay. ${ }^{20}$ Together, these three tenets were for a long time extremely important in shaping the health care system.

16. See, e.g., Entin, DRGs, HMOs and PPOs: Introducing Economic Issues in the Medical Malpractice Case, 20 Forum 674 (1985); Note, Rethinking Medical Malpractice Law in Light of Medicare Cost-Cutting, 98 HARV. L. REV. 1004 (1985).

17. See Havighurst, Altering the Applicable Standard of Care, Law \& Contemp. Probs., Spring 1986 , at $265,266-70$.

18. See Boulding, The Concept of Need for Health Services, in Economic Aspects of Health CARE 3 (J. McKinlay ed. 1973); Havighurst \& Blumstein, Coping With Quality/Cost Trade-offs in Medical Care: The Role of PSROs, 70 Nw. U.L. REv. 6, 25-30 (1975).

19. See Havighurst, Decentralizing Decision Making, supra note 1, at 29; Havighurst \& Bovbjerg, Professional Standards Review Organizations and Health Maintenance Organizations: Are They Compatible?, 1975 UTAH L. REv, 381, 401-06.

20. For a collection of ethicists' views showing strong egalitarian tendencies, see R. BAYER, A. Caplan \& N. Daniels, In Search of Equity: Health Care Needs and the Health Care System (1983). 
It is beside the point being made here that the foregoing tenets were never consistently adhered to in practice, that medical practice in fact varied widely even without regard to financial limitations, ${ }^{21}$ and that the nation never came close to realizing its oft-professed egalitarian ideal. ${ }^{22}$ It was not the practical validity and virtues of these tenets but their ideological and political appeal that caused the public to accept for so long the paradigm they rationalized. A brief review of the declining status of these three tenets-or myths-will show that society is indeed, as has been suggested, moving away from the traditional conception of a unitary health care system producing a single standardized product. The relevance for the malpractice debate of the new ideas that are asserting themselves in the health care sector will appear in the subsequent discussion.

1. From Entitlement to Consumer Good. During the long period in which passive third-party payers, government, and philanthropy made resources freely available to physicians, the cultural values of the medical profession came to define the quality of medical care solely in terms of what was ( $a$ ) technically feasible and $(b)$ deemed by physicians to be desirable. ${ }^{23}$ The tenet that professionally recognized needs rather than patient-initiated demand should govern the flow of resources to health care rested on several assumptions: first, that patients seeking health care were ignorant of where their welfare lay; second, that medicine was a science capable of objectively identifying the precise diagnostic and therapeutic steps that were appropriate in every case; and third, that practitioners and the medical profession as a whole were guided exclusively by scientific principles and technical considerations and could therefore be generally trusted to use resources wisely. ${ }^{24}$ The central implication of these assumptions was that cost and the patient's willingness to pay should not be factors in medical decisionmaking. As consumers and their agents find themselves unable to afford the consequences of this implication of the old dogma, the view that each patient is entitled to receive whatever services are deemed necessary by professional consensus is losing its hold in the new health care marketplace.

21. Consider in particular the research findings of John Wennberg, M.D., in Dealing with Medical Practice Variations: A Proposal for Action, Health AfF., Summer 1984, at 6-32. Dr. Wennberg's article is part of a recent symposium, Variations in Medical Practice, Health Aff., Summer 1984, at 1 [hereinafter cited as Symposium].

22. See, e.g., L. Aday, R. Andersen \& G. Fleming, Health Care in the U.S.: Equitable for Wном? (1980).

23. See sources cited supra notes 18-19; V. Fuchs, What Price Equity? Health, Economics and Social Cholce 60 (1974) (noting that a physician's decisions are guided by a "' technological imperative'-namely, the desire . . . to do everything that he has been trained to do regardless of the benefit-cost ratio"').

24. In recognition of the loss of patient autonomy that results from assigning decisionmaking responsibility exclusively to physicians, law and professional ethics have required providers to obtain a patient's informed consent to risky procedures. This effort to redress the effects of denying consumers opportunities to make choices in the marketplace did not satisfy all observers, however, for a persistent criticism of the old health care system was that it made patients dependent and treated them as incompetent decisionmakers. See, e.g., Canterbury v. Spence, 464 F.2d 772, 779-88 (D.C. Cir. 1972). 
Although the medical profession's advocacy of quality in medical care without regard to cost appeared to reflect a sincere concern for patient welfare, it also served providers' economic interests. Not only did the suppression of normal economizing impulses pave the way for expansive and demand-increasing definitions of the need for the providers' own services, but it also allowed providers to set their fees and charges on a noncompetitive and therefore highly lucrative basis. Whether professional values were sincere or merely served to rationalize self-interest is not an important question. The more significant point is that these values were aggressively used to justify a variety of public and private actions that together helped to lock the system into a mold highly advantageous to providers and costly to consumers. ${ }^{25}$ Without cost as a consideration in its dealings with patients and third-party payers, the health care industry benefited handsomely from the demand expansion induced by third-party financing. ${ }^{26}$

The market conditions and ideological climate fostered by the health care establishment led providers and patients alike to view health care as an openended, standardized entitlement, and not as a market commodity that might be purchased in a variety of forms or consumed in varying quantities depending upon whether additional services seemed worth their cost. Under the conventional view, any appreciable financial obstacle (besides routine cost-sharing) placed in the way of professionally acceptable therapy was viewed as a violation of the patient's entitlement and not as a normal constraint helpful in ensuring that resources were put to their best uses. So effective was the medical profession in fostering its preferred perception of health care as a professionally defined entitlement that consumer groups and political spokesmen came to accept it without question. Indeed, the aura surrounding physicians and the symbolism surrounding medical care in general were such that even private insurers and employers, who paid the bills, shrank from challenging providers' judgments and accepted the commitment to pay for all "medically necessary" services. Similarly, the federal government, in undertaking to finance health care for the elderly and the poor, also agreed to pay for any desired service that could not be shown to

25. One such restraint was the professional canon holding it unethical for a physician to engage in "contract practice"- that is, to market his services under contract to an independent third-party payer or other intermediary who, in effect, retailed professional services to the public. See American Med. Ass'n v. Federal Trade Comm'n, 94 F.T.C. 701, 1011-16, modified and enforced, 638 F.2d 443 (2d Cir. 1980), affd by an equally divided Court, 455 U.S. 676 (1982). Such "corporate practice of medicine" by lay-controlled middlemen was also frequently prohibited by law, ostensibly to preserve the physician/patient relationship and to prevent the intermediary's financial concerns from affecting professional judgment. See, e.g., 65 Op. Cal. Att'y Gen. 223, 227 (1982). Similarly, the medical profession, by political efforts and occasional coercive measures, was long able to enforce its view that there should be no interference with patients' "free choice of provider." See M. Olson, Foreword to A New Approach to the Economics of Health Care at 1 (1981). In addition to inhibiting the development of closed-panel HMO's and similar arrangements, the free-choice requirement usually meant that payers could not offer patients inducements to avoid higher-cost physicians or hospitals.

26. On the need to minimize the demand- and cost-increasing effects of moral hazard when providing insurance coverage, see P. Joskow, Controlling Hospital Costs: The Role of Government Regulation 20-31, 36-43 (1981). On the inhibiting effects of provider restraints on insurer cost-containment efforts, see Havighurst, Professional Restraints, supra note 7. 
have been irresponsibly prescribed. ${ }^{27}$ Spokesmen for all interests routinely urged providers to be socially responsible, and many endorsed regulation to limit the resources available for providers' use. Nevertheless, although these attempts to control costs revealed certain doubts about the validity of the assumptions underlying the dominant paradigm, they also demonstrated the entrenchment of the entitlement mentality and policymakers' reluctance to challenge directly the paradigm itself.

A vital feature of the medical profession's effort to maintain the view that health care is a standardized commodity and to exclude cost considerations from consumer and insurer calculations was the establishment of the profession itself as the arbiter of what care was appropriately provided and financed. In order to justify its opposition to, and to head off, efforts by payers and other middlemen to impose their own cost controls, the profession sponsored peer review bodies to detect abuses and resolve inevitable disputes by reference to professional standards. ${ }^{28}$ Insurers, anxious to avoid physicians' displeasure, tended to accept this assertion of professional authority, perhaps in part out of a natural disinclination to compete among themselves in the difficult business of controlling medical practice. Similarly anxious not to violate the entitlement principle, government, too, delegated to profession-sponsored bodies-so-called Professional Standards Review Organizations-the task of identifying the services for which it would pay. ${ }^{29}$ In effect, society, implicitly accepting the premise that medical science alone should define the scope of every citizen's entitlement to health services, turned over to the providers of those services the task of deciding which of them society should purchase.

Recent events have severely undermined the entitlement mentality that guided for so long the provision, consumption, and financing of health services. Gradually, those who pay for such services have come to appreciate that health care is not all of one piece, that much of it is of debatable value, that there are important trade-offs that cannot be ignored, that patients' needs and circumstances differ, that consumer tastes for health services vary, and that providers are inclined to attach inflated values to the services they are asked to ration. Under the Medicare program's new policy of paying fixed allowances for treating various conditions, providers must now adjust their practices to the resources made available by government instead of the other way around. Similarly, the awakening of private responsibility for health care costs has induced the market to offer new opportunities to economize, and purchasers, including consumers themselves, are finally beginning to face the fact that they cannot necessarily have it all and that choices must sometimes be made. Although consumers have begun to learn that economizing can be

27. The Medicare law committed the government to pay for all care that was "reasonable and medically necessary." 42 U.S.C. § 1320c-3(a)(1)(A) (1982). See infra text accompanying notes 28-29.

28. For instances of the use of such peer review bodies to resolve fee-related issues, see Union Labor Life Ins. Co. v. Pireno, 458 U.S. 119 (1982); Iowa Dental Ass'n, 3 Trade Reg. Rep. (CCH) I| 21,918 (FTC Advisory Opinion, Apr. 9, 1982).

29. See Havighurst \& Blumstein, supra note 18 , at 7-8. 
safe, their natural caution makes the learning curve rise only slowly over time. Nevertheless, progress in forcing cost-containment responsibilities on private purchasers has launched a major reevaluation of health care's marginal benefits and stimulated the hitherto neglected search for efficiency in the use of scarce resources.

The shift away from thinking of health care as an entitlement owes a great deal to new recognition that the medical profession's standards are both less uniform and less reliable than the old paradigm assumed. Recent scholarship revealing wide and inexplicable variations in clinical practice from area to area $^{30}$ suggests that the profession was not in fact, as the paradigm implied, marketing a uniform product with characteristics authoritatively validated by medical science. Instead, it appears that the profession regularly tolerated costly practices when more economical methods might have served patients equally well. Moreover, other health services research has raised serious questions about the efficacy, safety, and efficiency of many practices long sanctioned by medical custom. ${ }^{31}$ In addition to these reasons for declining faith in professional consensus, consumers have now had extensive and generally satisfactory experience with HMO's-mechanisms that the medical profession has long criticized and that depart in significant respects, most notably in their propensity to hospitalize, from the standards of traditional practitioners. ${ }^{32}$ Having lost confidence in the collective prescriptions of the medical profession, consumers are now beginning to accept the necessity for deciding for themselves or for depending upon intermediaries other than the medical profession to choose on their behalf. In short, they are beginning to treat medical care less like an entitlement and more like a consumer good and, in so doing, are weighing their new options with a view to getting good value for their money.

2. From Entitlement to Merit Good. The old notion that health care, as defined by the medical establishment, was an entitlement of the average citizen carried over naturally into the proposition that, even for those who could not afford to pay, "health care is a right." This proposition was widely heard in the early 1970's and served as the rallying cry of those who sought to complete the movement, begun by the enactment of Medicare and Medicaid, towards national health insurance. Even without a formal governmental guarantee of equal access to standard medical care, however, it was widely

30. See generally Symposium, supra note 21.

31. Indeed, one noted researcher has observed that "there is reason to believe that there are flaws in the process by which the profession generates clinical policies." Eddy, Clinical Policies and the Quality of Clinical Practice, 307 New EnG. J. MEd. 343, 343 (1982). See generally J. Bunker, B. Barnes \& F. Mosteller, Costs, Risks and Benefits of Surgery (1977); A. Cochrane, Effectiveness and Efficiency-Random Reflections on Health Services (1972); Office of Technology Assessment, The Implications of Cost-Effectiveness Analysis of Medical Technolocy (1980). 32. See generally H. Luft, Health Maintenance Organizations: Dimensions of Performance (1981); Havighurst \& Bovbjerg, supra note 19; Manning, Leibowitz, Goldberg, Rogers \& Newhouse, A Controlled Trial of the Effect of a Prepaid Group Practice on Use of Services, 310 NEw ENG. J. MED. 1505 (1984). 
believed that "two-tier medicine" was unacceptable and that a patient's inability to pay should not affect the quality of care he could obtain. Although this egalitarian ideal was widely violated, many hospitals were able, by exploiting the passive payment system, to generate the funds they needed to cross-subsidize indigent care; indeed, by this expedient they were often able to provide very good care to nonpaying patients. It is ironic that the medical profession, while claiming to oppose "socialized medicine," fostered and presided over a health care system that aggressively redistributed income to the sick poor and tended to homogenize under central authority the health care available to the entire population.

The egalitarian ideal was also at the heart of the health policy agenda of the 1970 's. ${ }^{33}$ On the regulation front, centralized health planning, certificateof-need laws, and hospital rate and revenue controls were enacted or advocated in the explicit expectation that they would ensure that all Americans had equal access to quality care; similarly, national health insurance plans were proposed and seriously studied throughout the period with a view toward giving solid statutory and financial backing to the widely recognized entitlement. Before a complete regulatory infrastructure for the industry was in place, however, the political climate shifted, and Congress began to lose enthusiasm for economic regulation and to recognize the failures of similar regulation in other industries. Simultaneously, recession and inflation reduced government's ability to finance new social programs, and national health insurance was continually deferred, in part for this reason but also because it was becoming increasingly doubtful that more money spent on health programs would produce significant improvements in health. Subtle changes in relevant political attitudes were reflected in increasingly frequent observations that good health was a product not only of health care but also of life style, nutrition, exercise, smoking habits, and so forth; as poor health was seen more and more as a personal responsibility, restorative health care was less frequently declared to be a "right."

The idea that health care, broadly and authoritatively defined, was an entitlement of all Americans and should be distributed on an egalitarian basis has been another casualty of recent developments. Governmental decisions to control Medicare and Medicaid costs independently of costs in the private sector represented a significant break with the traditional view that public program beneficiaries were entitled to exactly the same care that selfsupporting individuals obtained. Just as this policy change was occurring, a prestigious presidential commission, charged with appraising ethical issues in health policy, declared that, although all citizens should be given basic protection, it was not ethically imperative that everyone receive identical

33. See generally Havighurst, The Debate over Health Care Cost-Containment Regulation: The Issues and the Interests, in Incentives vs. Controls in Health Policy: Broadening the Debate 9 (J. Meyer ed. 1985). 
care. ${ }^{34}$ A subtle but important feature of this commission's work was that it stressed the societal obligation to provide, rather than the individual's right to receive, publicly financed health care. Thus, under the new paradigm that is emerging, most rights to particular health care do not exist in the abstract but must instead be clearly expressed in a statute or a contract before they will be recognized in law. This new view results in large measure from the new appreciation that health care is not a uniform good to which one can sensibly be said to have a right but is instead a set of services of highly variable value and content that may or may not be desirable enough in particular circumstances to warrant embodiment in a contractual or statutory entitlement.

The most disturbing recent development affecting the health services available to the poor has been the erosion, through price competition, of the provider revenues that previously allowed liberal cross-subsidization of care for those who lacked both the ability to pay for care and eligibility for public support. Regrettably, this development has made it necessary for government, in a time of straitened circumstances, to seek new resources with which to finance health services for these citizens. Although the hardships being suffered while this search for new public funds goes on are undeniably a result of the new, procompetitive health policy, they are most accurately viewed as regrettable side effects-not as an intended result-of the coming of price competition. In this respect, the problem is no different from that arising in any newly deregulated industry and should probably be construed here, as in those cases, merely as part of the price of strengthening incentives for efficiency. ${ }^{35}$

Current efforts at the state and local levels to replace with public funds the hidden subsidies by which the old system financed indigent care make little pretense that the object of public policy is to give the poor access to the same mainstream care that is available to the middle class. Nevertheless, even though access to a single uniform standard of health care seems no longer to be generally regarded even in theory as an entitlement of all Americans, health care in this society surely remains a merit good-that is, a commodity that people value for others besides themselves and do not wish to see allocated solely on the basis of ability and willingness to pay. ${ }^{36}$ Even as Americans increasingly purchase health plans and health services for their

34. President's Comm'n for the Study of Ethical Problems in Medicine and Biomedical Research, Securing Access to Health Care: The Ethical Implications of Differences in the Availability of Health Services (1983) [hereinafter cited as President's Commission].

35. Economic regulation of transportation, communications, and other industries has universally had as one object, or at least one side effect, the facilitation of cross-subsidization by the protected firms of desirable activities that the market for some reason would not support. The introduction of competition has usually hurt the beneficiaries of these hidden subsidies. The policy of promoting competition in health care is having similar side effects. See C. Havichurst, Deregulating the Health Care Industry 277-85, 427-30 (1982); Havighurst, supra note 33, at 16 19.

36. On the concept of merit goods, see R. Musgrave \& P. Musgrave, Public Finance in Theory and Practice 65-66 (2d ed. 1976). On the public's perception of health care as a merit good, see President's Commission, supra note 34, at 1-6. 
own consumption in the same way that they would purchase a new car or other consumer good, they still regard health care as something special when it comes to providing it to those who cannot pay. Like education, basic health care is deemed vital to ensuring equality of opportunity, and its provision to disadvantaged citizens helps Americans believe in the basic justice of their society.

Although some will regret the demise of the egalitarian ethic and many will fear that the majority will provide inadequately for the disadvantaged minority, it is doubtful that Americans, with their new sophistication concerning the value of marginal health care, will return to the naive view that everyone is entitled to some centrally defined quantum and quality of health services. Instead, with their new perception of health care as a merit good rather than a standardized entitlement, policymakers will concentrate their attention on deciding what particular services are truly in the merit good category. ${ }^{37}$ In time, a new entitlement, either to particular services or to a fixed dollar subsidy (that is, a "voucher") that an individual can use to enroll in a private health plan, is likely to emerge as a way of honoring society's commitment to guarantee basic health services to all.

\section{III}

\section{Opportunities for Enhancing Consumer Welfare Through Privately Negotiated Tort Reforms}

The changing public policies, market conditions, and perceptions reported above reveal that Americans are increasingly comfortable with the notion that, even in purchasing a professional service as complex and vital as health care, consumers can make choices, that economizing choices can be rational, that different people may elect to purchase different things, and that society need not rely solely upon professional consensus or government to define what patients are entitled to receive. Even though the revolution in ways of purchasing and thinking about health care is far from complete (certainly there is no shortage of rhetoric expressing the old views), the decentralization of decisionmaking is now far enough advanced in practice ${ }^{38}$ to reveal both fundamental problems in the law of medical malpractice and new

37. For a debate over the decline of the entitlement view, see Blumstein, Rationing Medical Resources: A Constitutional, Legal, and Policy Analysis, 59 Tex. L. REv. 1345 (1981); Rosenblatt, Rationing "Normal" Health Care: The Hidden Legal Issues, 59 TEx. L. REv. 1401 (1981); Blumstein, Distinguishing Governmeni's Responsibility in Rationing Public and Private Medical Resources, 60 TEx. L. Rev. 899 (1982); Rosenblatt, Rationing "Normal" Health Care Through Market Mechanisms: A Response to Professor Blumstein, 60 Tex. L. Rev. 919 (1982).

38. Measuring the progress of a revolution is difficult, but one opinion pollster concludes as follows:

Historians looking back on the 1980s will report that the nation's health care system was profoundly changed during this decade. They will note . . increasing competition among health care providers; fundamental changes in delivery of health care services and in the institutions that deliver them; and a revolution in the way that health care services are sold and paid for. They may also be able to note that-after years of escalating health care costs-private sector costs were brought under control. And, if they are perceptive, they will report that the 
opportunities for solving those problems by private contract. Malpractice law can now be seen as a factor raising the cost of medical care both by compelling patients to pay for protection they may not need and by inhibiting desirable economizing in medical practice. In addition, in a market which has seen other kinds of economizing and in which consumers have both sophisticated allies looking out for their interests and a range of real alternatives, it should be possible to view contractual modifications of consumers' tort rights as further efforts to enhance consumer welfare. Just as consumers are coming gradually to realize that there is more than one right way to organize the financing and delivery of health services and often more than one acceptable way to treat particular medical conditions, they may eventually appreciate that the legal system does not have a monopoly on wisdom when it comes to devising liability rules and incentive systems.

\section{A. Why Private Malpractice Reform May Be Desirable}

The next step in the argument here is to show more precisely why private reforms might be desired by the parties to particular health care transactions-not only by providers seeking to limit their liability exposure but also by consumers who stand to lose their chance at a big tort award. Reduction of the high cost of operating the current reparations system is perhaps the most obvious source of benefits from modifications of the rules governing liability for medical injuries. Upwards of sixty percent of what providers pay into the system (and must build into their charges to consumers) goes to pay administrative costs, particularly attorney fees. ${ }^{39} \mathrm{~A}$ consumer might be forgiven for concluding that this costly liability system is not maintained primarily for his benefit. Even if he does not distrust the motives of those designing that system, he might judge that his own insurance coverage supplies all the financial protection he needs and thus justifies his declining some or even all of the tort system's duplicative protection. He might also conclude that malpractice law, while extravagantly compensating a few patients, protects against only a small subset of the many risks that patients face-namely, those injuries that result from provable negligence. In order to benefit from the system at all, the injured patient must be willing to put his fate in a lawyer's hands, to challenge publicly the professional competence of the health care providers who took care of him, to undergo the emotional and other burdens of drawn-out litigation, and to await, perhaps for years, a highly uncertain outcome. Given a chance to opt out, consumers

public's behavior, attitudes, and expectations about health care providers also shifted dramatically.

Some things have not changed, including our priorities. Americans want a health care system that provides first-rate care with a human face, that is accessible to everyone, including the old and the poor, and that is affordable.

Taylor, Healing the Health Care System, Pub. Opinion, Aug./Sept. 1985, at 16. It seems likely that changes in behavior precede changes in attitudes expressed to pollsters.

39. See P. Danzon, supra note 1, at 186; see also O'Connell, An Alternative, supra note 1, at 503-10 (estimating that only $28 \%$ of the premium dollar goes finally to patients). 
might well elect not to pay the fee necessary to enter this costly and potentially trying game of chance.

Of course, the tort system does not exist solely to ensure compensation for grievous injury, and patients will not fail to perceive that the greater value of the system to them may lie in its in terrorem effect on providers. ${ }^{40}$ Although the discretionary right to register a grievance by suing a physician or hospital will be valued more by some consumers than by others, all should see its possible utility in inducing a provider's best efforts, not only to avoid a bad outcome (or at least actionable negligence), but also to earn the patient's loyalty so that an injury is less likely to trigger a lawsuit. ${ }^{41}$ Experts differ, however, on the incentive effects of tort law. Indeed, few besides plaintiffs' lawyers regard the existing malpractice system as an ideal mechanism for deterring injuries. ${ }^{42}$ For one thing, liability insurance spares a provider from feeling the financial consequences of a claim directly, leaving as the main (although perhaps unreliable) sanctions the stigma, publicity, and emotional pain of facing a charge of professional incompetence. Some consumers might judge that the incentives supplied by the tort system are not needed to ensure the quality of the care they receive in a particular setting, believing, for example, that the peer review mechanisms operating in a given hospital, $\mathrm{HMO}$, or other organized practice setting provide adequate correctives and disincentives for poor practice. Alternatively, they might decide that, although it is wiser to reserve their right to sue, some modification of their legally prescribed rights, some reduction in their potential financial recovery, or some change in factfinding procedures would provide appropriate incentives at a more reasonable cost.

Consumers and their representatives might also recognize that tort law, while possibly deterring some negligence, may also have perverse incentive effects. Assertions that the legal system compels the practice of "defensive medicine" are difficult to evaluate definitively, ${ }^{43}$ but it is plausible that the

40. On the need for preserving tort remedies to deter bad medical practice and bad outcomes, see P. DAnzon, supra note 1, at 9-17; Schwartz \& Komesar, Doctors, Damages and Deterrence, 298 NEW ENG. J. MED. 1282 (1978). The leading exposition of the view that tort law should seek to achieve economic efficiency by minimizing not the cost of accidents but the total of the costs of accidents and accident avoidance is G. Calabresi, The Costs of Accidents: A legal and Economic Analysis (1970).

41. Consumers may value their right to sue precisely because it assures them that their welfare will not be neglected and that it enhances the respect they receive from the other party to any transaction. It is widely noted that patients who are treated decently are less likely to sue in the event of mishap.

42. Though she advocates deterrence, Danzon also advocates substantial reforms of malpractice law to improve its contribution to efficient provider performance. P. Danzon, supra note 1 , at 17. Others believe that deterrence is greatly overrated as a justification for personal injury litigation. See, e.g., Sugarman, Doing Away with Tort Law, 73 Calif. L. Rev. 555, 559-91 (1985).

43. Several contributors to this symposium show how inconclusive discussions of defensive medicine necessarily must be: Bovbjerg, Medical Malpractice on Trial: Quality of Care is the Important Standard, Law \& Contemp. Probs., Spring 1986, at 321; Robinson, Rethinking the Allocation of Medical Malpractice Risks Between Patients and Providers, Law \& ConTemp. Probs., Spring 1986, at 173, 175-80; Zuckerman, Koller \& Bovbjerg, Information on Malpractice: A Review of Empirical Research on Major Policy Issues, Law \& Contemp. Probs., Spring 1986, at 85, 106-09. 
cost of medical care is raised unnecessarily by providers' efforts to make themselves look good in the event of a subsequent lawsuit. Moreover, the easy availability of third-party payment has long made it possible for providers to spend freely on tests and extra services that served more to protect themselves against perceived legal risks than to protect patients against bad medical results. To the extent that such excessive spending became standard practice, it was risky for any provider to omit the defensive measure, because any departure from medical custom was likely to be judged negligence under the usual legal tests. ${ }^{44}$

The tort system's contribution to misallocation of resources in the health care sector results from more than the pressure it puts on providers to adopt practices that physicians recognize as being more defensive than useful. Malpractice law tends to presume that customary practice, because it reflects professional consensus, is necessarily good practice. ${ }^{45}$ To the extent that customary practice develops in a system lacking significant cost constraints, however, it may be highly inefficient. In ignoring this possibility, the law has not only encouraged inefficient defensive medicine, but it has also embraced the old idea that cost is no object, that anything arguably beneficial to the patient should be done. Thus, malpractice doctrine embodies the presumption that there is one correct standard of medical care, that this standard is discoverable in medical consensus, and that all patients are entitled to enjoy care meeting this centrally defined standard. In short, the law manifests all the premises of the old, unitary health care system and stands as one of its last remaining bulwarks. As the old paradigm weakens in practice, however, consumers and their representatives, seeking greater efficiency in the provision of health care, might reasonably seek to relieve providers of the tort system's compulsion to practice defensively and according to costly, unverified professional standards.

The deficiencies of the existing tort system are inviting close legislative attention at the moment, just as they did in the 1970 's. ${ }^{46}$ Reforms are likely to be slow in coming, however, in part because legislators are naturally reluctant to deprive patients of their basic right to seek redress from providers for the harms they do. Even though this basic right is not overwhelmingly valuable to

44. See Havighurst, supra note 17 , at 266-70.

45. See id. In Helling v. Carey, 83 Wash. 2d 514, 519 P.2d 981 (1974), the court refused to accept adherence to custom as a defense and imposed a standard of its own devising on ophthalmologists. A similar willingness to second-guess medical standards is reflected in cases doing away with the socalled locality rule and holding local practitioners to higher standards prevailing in other places. See, e.g., Naccarato v. Grob, 384 Mich. 248, 180 N.W.2d 788 (1970). The point to be made here is that customary practice may be more demanding, not less demanding, than responsible use of resources requires. It is a telling commentary on the judicial performance in the Helling case that medical research taking all relevant factors into account provides no convincing evidence for the costeffectiveness of even the customary practice of screening all patients over age 40 for glaucoma. See Eddy, Sanders \& Eddy, The Value of Screening for Glaucoma with Tonometry, 28 SURV. OPHTHALMOLOGY 194, 201 (1983). The Washington court, which held on the basis of its own intuition that it was negligence not to screen the plaintiff because she was under 40 , is thus left with egg on its face.

46. See Robinson, The Medical Malpractice Crisis of the 1970's: A Retrospective, LAw \& Contemp. Probs., Spring 1986, at 5. 
consumers, it symbolizes a matter of great political significance-the distribution of power in the physician/patient relationship. The issue of patient rights therefore has greater salience and impact than cost considerations in the political debate. Because it is always providers who raise the cost issue and because they bear the system's costs in the first instance in the form of insurance premiums, providers naturally appear to be the sole beneficiaries of any legislative modification of patients' remedies. Unlike consumers negotiating with providers over price and the precise terms of their future relationship, legislators and their constituents do not see clearly the cost savings that consumers may enjoy as a result of legal changes reducing provider costs. Instead, legislators view themselves as being asked to take from consumers and give to providers. Under these conditions, they may make only minimal reforms. ${ }^{47}$

The political difficulty of legislating malpractice reforms should not be taken as a sign that a legislature believes that the legal system has found the single best way to allocate the risk of patient injuries. Legislative inaction-or action, as the case may be-is equally consistent with the idea that there is no one right way to define provider/patient relationships but that patients should be presumed, in the absence of a contrary provision in an explicit contract, to have certain basic rights to legal redress. There is thus nothing in a legislature's definition of an implied contract between provider and patient that should preclude patients from waiving their legally conferred rights in particular instances in return for explicit or implicit concessions by providers. If patients do not value their potential tort rights highly and providers wish strongly for relief from the law's burdens, there is ample room for a mutually beneficial reallocation of risks. It is perhaps most helpful to think of the tort system maintained under the legislature's auspices simply as a starting point for negotiations, one that arms consumers with substantial bargaining power with which to negotiate for price reductions or other benefits. ${ }^{48}$

47. There should be no implication, such as Professor Atiyah draws, from the proposal to encourage private reforms that legislative reforms should not also be pursued. See Atiyah, Medical Malpractice and the Contract/Tort Boundary, Law \& ConTemp. Probs., Spring 1986, at 287, 300. Professor Atiyah properly couples his preference for legislative or judicially imposed reforms with a recognition of the difficulty, especially in the American system, of achieving major improvements by this route. Indeed, given his preference for centrally imposed rules, his concession "at the end of the day" that the private reform option is better than no alternative at all, id. at 302 , is a striking one.

48. This conception shows why advocacy of greater judicial receptivity to private reforms does not amount, as Atiyah suggests, to a proposal "to shift the control of much of the physician/patient relationship from tort to contract." Id. at 287 . Instead, the objective is simply to provide a kind of safety valve by which parties can, if they choose, opt out of the tort system.

The great insight of Ronald Coase in his classic article, The Problem of Social Cost, 3 J. LAw \& Econ. 1 (1960), was that tort rules affect the allocation of resources only because parties whose interests conflict cannot costlessly negotiate with each other to ensure the least-cost solution. In the real world of limited information and high transaction costs, there would appear to be good efficiency reasons to make health care providers bear the risk of accidents because they are likely to be, in Calabresi's phrase, the "cheapest cost avoiders"- that is, to be in the best position to assess and reduce particular risks. G. Calabresi, supra note 40, at 135-73. Nevertheless, a legal rule prohibiting explicit contracts shifting or redefining this risk-in effect making transaction costs infinite-would appear to destroy important opportunities for increasing efficiency still further. The problem is 


\section{B: Some Specific Suggestions for Private Reform}

There are many kinds of contractual modifications of tort rights that might make sense both to particular consumers and to the providers with whom they contract for future services. Some would relate only to the factfinding and faultfinding processes employed. ${ }^{49}$ Arbitration clauses may reduce litigation costs, improve the quality and consistency of decisions, increase the ease and speed with which claims may be brought and disposed of, and limit the publicity and offensive adversariness that providers and some patients find so distasteful in the present system. It is possible that other arrangements for screening out nonmeritorious claims could also be stipulated by contract. Providers and patients might also agree on the allocation of legal costs, perhaps providing that the loser in any litigation would pay all attorney fees. ${ }^{50}$

Another reasonable way to modify tort remedies would be to limit the size of recoveries. ${ }^{51}$ Private contracts might preclude or limit recovery for pain and suffering, mental distress, and other noneconomic loss in some or all cases or provide for the exclusion from awards of amounts that duplicate benefits available to the patient from certain collateral sources, such as health or disability insurance. Because consumers do not customarily purchase insurance protection against other than out-of-pocket losses, they appear to attach only low value to the duplicative or excessive protection provided by the tort system. As noted above, however, they might also be cautious about removing incentives for providers to render high-quality or more personalized, attentive care.

Rational patients might also agree to changes in the substantive obligations of providers, substituting a contractual standard of care for the common law standard of care applicable in a suit for damages. ${ }^{52}$ A primary objective of redefining the expected standard of performance would be to improve the climate for efficient behavior by eliminating pressures to practice unnecessary defensive medicine and to adhere to inefficient professional standards. For example, state tort doctrine binding an HMO to adhere to community practice standards might be expressly declared inapplicable to the HMO's physicians in order to facilitate responsible economizing that the HMO could otherwise undertake only at the risk of having to pay for every unsatisfactory outcome that might occur. Moreover, because patients may

especially acute where, as in medical care, the strict liability approach is unfeasible and the cost of shifting particular losses (those caused by negligence) is therefore particularly high.

49. See Henderson, Agreements Changing the Forum for Resolving Malpractice Claims, LAw \& ConTEMP. Probs., Spring 1986, at 243.

50. Fla. STAT. $\$ 768.56$ (1985) makes limited statutory provision for such fee shifting, which may discourage the bringing of nonmeritorious suits, encourage prompter settlements, and reduce overall costs by giving each party a potential stake in limiting the other's legal expenses. Unlike the Florida law, the parties' contract might provide that a plaintiff's attorney taking a case on contingency would assume the plaintiff's potential obligation for the defendant's legal costs. See generally Attorney Fee Shifiting, Law \& Contemp. Probs., Winter 1984.

51. See Ginsburg, Kahn, Thornhill \& Gambardella, Contractual Revisions to Medical Malpractice Liability, Law \& Contemp. Probs., Spring 1986, at 253, 258-59, 262-63.

52. See Havighurst, supra note 17. 
place a low value on their right to go to court over all mishaps that a jury might be persuaded to treat as resulting from legal fault, a provider/patient contract might reasonably preclude lawsuits for all but gross negligence. ${ }^{53}$

Yet another approach might be to use fewer dollars to pay lawyers' fees and extravagant awards to a few patients and more dollars to compensate patients' real out-of-pocket losses. This reallocation could be accomplished by removing fault as the criterion of compensability and committing the provider to pay basic benefits for particular injuries, however they occur. ${ }^{54}$ In some ways, the substitution of such no-fault compensation for tort rights could improve provider incentives to achieve good medical results. Moreover, patients might be willing to pay more for the more rational and extensive financial protection that a no-fault scheme could provide. ${ }^{55}$

The foregoing suggestions for private reform of the tort rules governing medical injuries speak for themselves. Indeed, several of the ideas suggested for private implementation have already been adopted in some form by state legislatures. ${ }^{56}$ Others have been proposed for legislative action, ${ }^{57}$ and a persuasive argument can be made that each of them represents an improvement over the prevailing system, even when viewed exclusively from the standpoint of the consumer. (Obviously, it is wholly inappropriate to view the matter ex post rather than ex ante-that is, to judge effects on patient welfare after rather than before the occurrence of a regrettable event.) The fact that health care providers would also benefit from such voluntary reforms is simply a particularly vivid demonstration of the principle that private contracts are not a zero-sum game, in which one party can gain only at the expense of the other. Here, both consumers and providers can gain materially from voluntary revisions of the implied contract that the law supplies to govern their relationship when they have not themselves spelled out its terms. Although trial lawyers may be injured by the parties' voluntary adoption of arrangements that economize on the need for legal services, the public should not grieve for them. One hopes, of course, that legislators and judges, as denizens of the legal culture that produced the current tort rules, do not feel compelled to defend the system that has treated the trial lawyers so well-and consumers and providers so badly. ${ }^{58}$

53. See id. at $272-75$

54. See Tancredi, Designing a No-Fault Alternative, LAw \& Contemp. Probs., Spring 1986, at 277.

55. An attractive approach would be for the provider to offer the patient a chance to purchase (perhaps at a provider-subsidized price) insurance against the risks of, say, a particular hospitalization. Such coverage might be conditioned on a waiver of tort rights or at least on an agreement that any proceeds would be excluded from any tort award. Many variations of this approach, which can be likened to "flight insurance," can be imagined.

56. See Robinson, supra note 46 , at 23-26.

57. See id. at 32-35.

58. Professor Atiyah is correct in his perception that renewed emphasis on private contracting is being advocated to bring about specific reforms or at least to open the door to such reforms if people choose to adopt them. See Atiyah, supra note 47, at 298-300. More precisely, the proposal reflects a concern that the legal system embodies out-of-date conceptions and imposes severe burdens that could be alleviated by do-it-yourself reforms. 


\section{IV}

\section{Legal Obstacles to Private Reforms 59}

Although there is only sparse legal authority on the enforceability of contractual modifications of patients' malpractice rights, most lawyers would be inclined to doubt the courts' willingness to accept such provisions at face value and to hold that an injured patient had surrendered any right conferred upon him by the legal system. This skepticism concerning the enforceability of contracts derogating from consumers' tort rights reflects values and biases deeply embedded in the legal system, which frequently tends to view consumer contracts more as candidates for close judicial scrutiny and rewriting than as presumptively valid definitions of private rights and responsibilities. Although the broader implications of the legal system's hostility to contractual reallocations of risks will not be pursued here, the reader is invited to consider them. ${ }^{60}$ It will be suggested at the end of this discussion that the legal system's lack of enthusiasm for consumer decisions to economize on legal services betrays the same kind of professional hubris and self-aggrandizement that caused the medical profession for so long to deny the legitimacy of cost-conscious consumer choice in the medical field.

There are several signs of judicial reluctance to allow patients to waive their malpractice rights. One particularly suggestive case is Emory University $v$. Porubiansky, ${ }^{61}$ in which the Georgia Supreme Court refused to enforce an exculpatory clause signed by a patient patronizing a low-cost university dental clinic. The court's theory was not that the patient had been misled or that the clinic had overreached in some way but that the exculpatory clause violated public policy as expressed in a statute contemplating tort actions in the event of a professional's failure to exercise " 'a reasonable degree of care and skill." "62 A number of decisions in other states have also invalidated waivers

59. Several paragraphs in the following discussion are adapted, with the permission of the American Enterprise Institute for Public Policy Research, from Havighurst, Decentralized Decision Making, supra note 1 , at 35-37.

60. See Robinson, supra note 43, at 183-89; Atiyah, supra note 47 , at $288-91$. The latter reference cites literature advocating aggressive judicial imposition of "community values" and redistributive preferences in adjudicating private contractual disputes. Id. at $290 \mathrm{nn} .15-18$. There is a strong authoritarian streak in many of the scholars who would encourage judges to substitute their own view of what is right and fair for the rights and duties that the parties have privately agreed upon. Nevertheless, there are many instances in which contracts fail to reveal the parties' intent. In these cases some exercise of judicial discretion is unavoidable, and it is reasonable for it to be exercised by leaning toward the less powerful party. As in all disputes over judicial activism, the issue is one of degree-how quickly should courts conclude either that the parties were unclear or that the contract was unconscionable, adhesive, or unfairly negotiated and that therefore their own rather than the parties' preferences should govern. The point to be made here is simply that, when parties expressly and openly agree to a different set of rules governing medical injuries, the presumption should be in favor of and not against giving effect to the agreement. See id. at $291 \mathrm{n} .21$, (quoting and discussing C. Fried, Contract as Promise 60 (1981)).

61. 248 Ga. 391, 282 S.E.2d 903 (1981); see also Smith v. Hospital Auth., 160 Ga. App. 387, 287 S.E.2d 99 (1981).

62. Emary University, $248 \mathrm{Ga}$. at 393, 282 S.E.2d at 904 (quoting GA. CODE § 84-924 (1979) (current version at GA. CODE $\$ 51-1-27$ (1982))). 
of tort rights against health care professionals. ${ }^{63}$ All of these cases, however, involved attempts to shift all or virtually all of the risk of defendants' carelessness to patients. It is therefore arguable that they should not control the outcome of a case in which something substantially less than complete immunity is sought. In addition, these cases may also be distinguishable from cases emerging in the new health care marketplace on the ground that they all involved waivers by individual patients contracting with, and possibly being overreached by, powerful providers rather than arrangements negotiated on consumers' behalf by sophisticated employers or insurers.

In a few states, there may be statutes, such as Georgia's, that could lead a court to conclude that the legal system's rules are mandatory rather than merely prescriptions applicable in the absence of a contrary agreement between the parties. Illinois, for example, has a statutory section bearing the ungrammatical title, "Releases from liability ... is [sic] against public policy." 64 The coverage of other statutes may seem so all-encompassing and prescriptive as to invite the holding that their terms cannot be expressly overridden by private action. ${ }^{65}$ Nevertheless, carefully drawn agreements may be seen as involving something less than a "release" under the Illinois statute, as affecting only the patient's remedies and not a publicly protected right, or as fleshing out statutory policy and terminology, such as Georgia's reference to "a reasonable degree of care and skill." 66 If the parties appear to have used statutory policy as a point of departure and not to have violated the spirit of the statute, courts should not strike down their election to modify certain rights and responsibilities. Although legislation should usually not be essential to open the private pathway to malpractice reform, a legislature might be well advised to clear up any doubt by stating expressly that its prescriptions are not intended to preclude enforcement of inconsistent private agreements. ${ }^{67}$

Although existing law does not generally preclude responsible private modifications of malpractice rights, a court asked to rectify a hardship encountered by some individual plaintiff as a result of surrendering some legal right will not be easily convinced that the individual voluntarily assumed

63. See, e.g., Tatham v. Hoke, 469 F. Supp. 914 (W.D.N.C. 1979), affd, 622 F.2d 584 (4th Cir. 1980); Tunkl v. Regents of the Univ. of Cal., 60 Cal. 2d 92, 383 P.2d 441, 32 Cal. Rptr. 33 (1963); Meiman v. Rehabilitation Center, Inc., 444 S.W.2d 78 (Ky. 1969); Olson v. Molzen, 558 S.W.2d 429 (Tenn. 1977). For additional references, see Ginsburg, Kahn, Thornhill \& Gambardella, supra note 51 , at 253-54.

64. Public Act No. 82-280 § 19a-102, Ill. ANN. Stat. ch. 111, § 4478 (Smith-Hurd 1983).

65. See, e.g., Fla. STAT. $\$ 768.45$ (1983) (commencing with the words "In any action").

66. GA. CODE § 51-1-27 (1982); see supra text accompanying note 62 .

67. Legislation should not try to specify too much. The best approach might be simply to declare (1) that, except perhaps for pure exculpatory clauses, private agreements altering rights, remedies, and responsibilities of providers and patients should not be held unenforceable on the ground that they are against public policy and (2) that, even if such an agreement is found in a contract of adhesion, it will nevertheless be enforced unless the court is satisfied that, taking the agreement as a whole, it is unconscionable. The important thing is for the legislature to make clear, first, that it does not regard itself and the courts as the sole sources of wisdom on how medical injuries should be handled and, second, that the courts' supervisory role should be limited to preventing overreaching by providers in favorable bargaining circumstances. 
that particular risk. In no jurisdiction would contractual provisions be conclusive, particularly if bargaining power was arguably unequal, if disclosure was arguably incomplete, or if no other option was offered or readily available to the patient. As a result, providers not only must be careful to define and limit their obligations clearly but also must be prepared to demonstrate that the contracting process gave adequate assurance that the bargain struck accommodated the interests of both parties. Although broad waivers of liability-exculpatory clauses-may well be too much for most courts to swallow, ${ }^{68}$ less sweeping and less seemingly one-sided departures from the dictates of the tort system should be defensible if steps are carefully taken and a proper record is made.

Unfortunately, the foregoing conclusion is not very secure because of a lack of legal precedents. Moreover, lawyers' nervousness is heightened by recent decisions in which several state courts invalidated legislative reforms adopted in response to the malpractice crisis of the 1970's. ${ }^{69}$ Although many reforms were approved, some courts did not hesitate to second-guess legislative judgments under state constitutional principles, and it is natural to view these decisions as signs of judicial hostility to all revisions of patients' tort rights. Nevertheless, the constitutional role of courts in reviewing legislation differs fundamentally from their role in enforcing private contracts. ${ }^{70}$ Thus, decisions holding that legislatures lacked a constitutionally acceptable basis for taking away malpractice plaintiffs' rights manifestly do not govern instances where patients arguably surrendered those same or similar rights voluntarily. Quite a different set of legal doctrines governs in cases of the latter type, and the following discussion of these doctrines indicates that private argreements meeting reasonable requirements stand a fair chance of being upheld.

There are several theories under which courts would evaluate contractual provisions that derogate in some respect from the patient's right to recover for medical malpractice. The initial inquiry is likely to be to determine whether the contract in question is a "contract of adhesion"-that is, an

68. But see the provocative defense of such clauses in Robinson, supra note 43, at 184-97.

69. Doran v. Priddy, 534 F. Supp. 30 (D. Kan. 1981) (reinstating the collateral source rule); Aldana v. Holub, 381 So. 2d 231 (Fla. 1980) (invalidating screening panel requirement); Wright v. Central DuPage Hosp. Ass'n, 63 Ill. 2d 313, 347 N.E.2d 736 (1976) (invalidating pretrial hearing panel, maximum recovery limit); State $e x$ rel. Cardinal Glennon Memorial Hosp. v. Gaertner, 583 S.W.2d 107 (Mo. 1979) (invalidating screening panel requirement); Carson v. Maurer, 120 N.H. 925 , 424 A.2d 825 (1980) (reinstating the collateral source rule); Arneson v. Olson, 270 N.W.2d 125 (N.D. 1978) (invalidating entire reform act); Simon v. St. Elizabeth Medical Center, 3 Ohio Op. 3d 164, 355 N.E.2d 903 (Ohio Ct. C.P. 1976) (invalidating maximum recovery); Detar Hosp., Inc. v. Estrada, 694 S.W.2d 359 (Tex. App. 1985) (invalidating maximum recovery); State ex rel. Strykowski v. Wilkie, 81 Wis. 2d 491, 261 N.W.2d 434 (1978) (invalidating provision for structured payments).

70. Some courts have made the constitutionality of malpractice reform legislation under equal protection requirements turn on the existence of a true "crisis" warranting special legislative attention to that area (without also addressing other areas of tort law). E.g., Jones v. State Bd. of Medicine, 97 Idaho 859, 555 P.2d 399 (1976), cert. denied, 431 U.S. 914 (1977). Although the legal issue is quite different, a court might more readily enforce a contract altering a plaintiff's tort rights if it were affirmatively convinced that malpractice law as currently constituted and administered does not always serve consumer interests well. 
agreement imposed on a patient under circumstances limiting the patient's opportunity to bargain for a different arrangement or to choose an alternative provider. ${ }^{71}$ Although an adhesion contract may be enforced, a court can be expected to take special pains to assure itself that the terms of the contract were equitable. Moreover, even if a contract is not an adhesion contract, a court may still refuse to enforce a term that it finds unconscionable ${ }^{72}$ or that violates public policy in some respect. As noted above, blanket exculpatory clauses have been found to be inconsistent with general public policy toward professionals and thus held unenforceable regardless of whether the contracts containing them were adhesive. Courts are less likely to use these doctrines to invalidate a contract term, however, if they are satisfied by all the circumstances that the agreement was arrived at fairly.

Some help in identifying adhesion contracts comes from a series of California cases involving the enforceability of agreements to arbitrate future medical malpractice claims. ${ }^{73}$ Though notoriously plaintiff-oriented, the California Supreme Court has required malpractice plaintiffs lacking actual knowledge of the arbitration clause to submit to unwanted arbitration in accordance with their HMO subscriber contracts. The leading case is Madden v. Kaiser Foundation Hospitals. ${ }^{74}$ In that case, the state, acting as the plaintiff's employer, had agreed to the arbitration clause, and the plaintiff had selected the HMO from a menu of alternative plans, including some that did not require arbitration. The court upheld the clause, finding that the contract was not one of adhesion and that the state had implied authority as the plaintiff's agent to agree to the clause in question. In other cases, California courts have refused to enforce arbitration clauses because of differences in the bargaining circumstances. ${ }^{75}$ In one such case, the court refused enforcement because of the one-sided nature of the clause, which bound only the subscriber to arbitrate. ${ }^{76}$

71. See, e.g., Tunkl v. Regents of the Univ. of Cal., 60 Cal. 2d 92, 383 P.2d 441, 32 Cal. Rptr. 33 (1963) (exculpatory clause not enforced); Wheeler v. St. Joseph Hosp., 63 Cal. App. 3d 345, 357-67, 133 Cal. Rptr. 775, 781-91 (1976) (arbitration agreement not enforced); Obstetrics \& Gynecologists v. Pepper, - Nev. - , 693 P.2d 1259 (1985) (arbitration agreement not enforced); see also Henningsen v. Bloomfield Motors, Inc., 32 N.J. 358, 161 A.2d 69 (1960).

72. The doctrine of unconscionability allows a court wide discretion in deciding whether it can in good conscience enforce a contract term. Restatement (SECOND) of Contracts $\$ 208$ (1981); U.C.C. $\$ 2-302$ (1978). Such "substantive unconscionability" has been contrasted with "procedural unconscionability," which involves defects in the bargaining process similar to those leading to characterization of a contract as a contract of adhesion. Leff, Unconscionability and the Code-The Emperor's New Clause, 115 U. PA. L. Rev. 485 (1967).

73. See infra text accompanying notes 81-82. On the subject of medical malpractice arbitration agreements, see generally Henderson, Contractual Problems in the Enforcement of Agreements to Arbitrate Medical Malpractice, 58 VA. L. Rev. 947 (1972); Note, Medical Malpractice Arbitration: Time for a Model Act, 33 Rutgers L. Rev. 454 (1981).

74. 17 Cal. 3d 699, 552 P.2d 1178, 131 Cal. Rptr. 882 (1976).

75. See, e.g., Wheeler v. St. Joseph Hosp., 63 Cal. App. 3d 345, 357-69, 133 Cal. Rptr. 775, 783. 91 (1976). For a recent Nevada case, see Obstetrics \& Gynecologists v. Pepper, —- Nev. —, 693 P.2d 1259 (1985).

76. Beynon v. Garden Grove Medical Group, 100 Cal. App. 3d 698, 161 Cal. Rptr. 146 (1980). 
Although the Madden decision allowed the parties to alter an important feature of the tort system by contract, a future plaintiff could easily distinguish that case from one involving an attempted alteration of substantive rights. The court's decision rested firmly on the public policy favoring the use of arbitration to resolve disputes, a policy based on efficiency considerations. Thus, unless a future court could be independently persuaded of the possible desirability of substituting a different measure of damages, a different standard of care, or a different definition of compensable events for judicially set standards, it might refuse to enforce the contractual modification. Indeed, the court in Madden emphasized that the arbitration clause "does not detract from Kaiser's duty to use reasonable care in treating patients, nor limit its liability for breach of this duty, but merely substitutes one forum for another."77 Despite this technical distinction, however, an arbitration clause can affect substantive outcomes and cannot be entirely differentiated from other contractual modifications of the parties' rights and duties. Thus, the willingness of courts to enforce arbitration clauses indicates some prospect that other agreements would be enforced. ${ }^{78}$

In upholding the arbitration clause in Madden, the court emphasized that, in addition to bearing "equally on Kaiser and the members," it benefited the latter by "facilitat[ing] the adjudication of minor malpractice claims which cannot economically be resolved in a judicial forum."79 A court looking for comparable mutuality of benefit in each discrete provision of a contract would be troubled by the seeming one-sidedness of provisions altering substantive tort rights. Indeed, unless it was willing to assume, on the basis of satisfactory bargaining circumstances, that the patients had received compensating benefits in the form of a reduced price or otherwise, such a court would inevitably refuse to enforce any significant modification of judicially set standards. Nevertheless, such judicial paternalism might be tempered upon a showing that the contracting process gave consumers adequate opportunities to protect themselves. In any event, many courts are less paternalistic than California's and should be willing to accept the presumptive validity of private agreements. On the other hand, providers concerned that judges will insist upon demonstrable mutuality might feel that their best bet for obtaining relief

77. 17 Cal. 3d at 711,552 P.2d at 1186,131 Cal. Rptr. at 890 ; see also Doyle v. Giuliucci, 62 Cal. 2d 606, 401 P.2d 1, 43 Cal. Rptr. 697 (1965) (enforcing HMO arbitration clause).

78. It must be acknowledged, however, that Madden is narrowly interpreted by the California courts and by federal courts applying California law. See, e.g., McLaughlin v. Connecticut Gen. Life Ins. Co., 565 F. Supp. 434, 447-49 (N.D. Cal. 1983) (rejecting argument that Madden undercuts the rule that ambiguities in health insurance policies are resolved against the insurer); Fields v. Blue Shield, $163 \mathrm{Cal}$. App. 3d 570, 580-83, 209 Cal. Rptr. 781, 786-88 (1985) (viewing Madden as a threat to "long-established public policy principles in this state aimed at protection of the general public against highly refined legalistic [insurance policies] carefully designed for the benefit of the insurer"); Beynon v. Garden Grove Medical Group, 100 Cal. App. 3d 698, 705-09, 161 Cal. Rpir. 146, 149-52 (1980) (rejecting Madden as authority for an alleged agent to negotiate an especially burdensome arbitration clause).

79. 17 Cal. $3 d$ at 712,552 P.2d at 1186,131 Cal. Rptr. at 890 . 
lies in offering an explicit quid pro quo in the form of an alternative injury compensation system based on no-fault principles. ${ }^{80}$

Because the plaintiff in Madden had the protection of both his employer's representation of his interests and an opportunity to reject the HMO, it might be asked whether the absence of either of these two forms of protection-a sophisticated agent and individual choice-would change the result. This is an important question, since different arrangements found in the health care marketplace locate the responsibility for choice in different places. The most common pattern, however, is the one most in keeping with the Madden case. Under this model, the employer merely offers employees "multiple choice" among several plans that it initially selects. By allowing the individual employee to make, and benefit from, the final economizing choice, the employer avoids the charge that it shortchanged the workers for its own benefit. ${ }^{81}$ Although courts should probably accept the consequences of an economizing decision made by either the consumer himself or someone representing his interests, ${ }^{82}$ the closer one could come to the Madden paradigm the better the prospect that a contractual innovation would be enforced.

Insurance law also supports the impression that contracts modifying tort rights will be judicially enforced if the bargaining circumstances seem fair. Because insurance policies have all the earmarks of adhesion contracts, the law of insurance reflects extreme judicial reluctance to enforce contractual fine print. ${ }^{83}$ Nevertheless, courts are most apt to rewrite a policy to protect a consumer from hardship when the coverage excluded by the policy was not available to the insured from another source. ${ }^{84}$ If the insured had the opportunity to elect the broader coverage, it will be hard for him to persuade the court to invoke the insurance law doctrine of "reasonable expectations" to override the policy language. There would appear to be a close analogy to the case of a consumer who had and passed up an opportunity to select a health care plan that left tort rights intact.

The foregoing legal analysis points toward a rule that might uphold a contractual reallocation of injury risks if it was adopted in an employerstructured multiple-choice setting but not if it resulted from the interaction of an individual patient and an individual provider. Unfortunately, such a rule could be seen as discriminating unfairly against practitioners and hospitals who continue to attract patients on an individual basis. ${ }^{85}$ Not only would such

80. See generally Tancredi, supra note 54 .

81. See C. Havighurst, supra note 35, at 409-16.

82. See generally Robinson, supra note 43.

83. See Abraham, Judge-Made Law and Judge-Made Insurance: Honoring the Reasonable Expectations of the Insured, 67 VA. L. Rev. 1151 (1981); see also McLaughlin v. Connecticut Gen. Life Ins. Co., 565 F. Supp. 434 (N.D. Cal. 1983); Fields v. Blue Shield, 163 Cal. App. 3d 570, 209 Cal. Rptr. 781 (1985).

84. Abraham, supra note 83 , at 1155 .

85. Perhaps the PPO concept can be adapted to let a subset of fee-for-service providers in a community effectively and fairly offer their services on terms including a narrowing of patients' malpractice rights. Indeed, one can imagine a PPO organizer using relief from malpractice risks as an inducement to get providers to join in offering their services for a lower price. 
a rule effectively deny such traditional providers an equal opportunity to offer patients attractive alternatives to the existing tort regime, but it would leave them with little room to economize by departing from customary practice and perhaps also with a disproportionate share of potentially litigious patients. ${ }^{86}$ There is an unfortunate irony here. One of the strengths of traditional feefor-service medical practice is that it fosters individual choice of provider and highly personal physician/patient relationships. Yet the law, perceiving an imbalance of bargaining power in such relationships, creates protections that have the effect of forcing patients into making choices collectively ${ }^{87}$ and into receiving care in more bureaucratic settings. It would be unfortunate if judicial hostility to individual choice of liability rules should create an artificial competitive advantage for those health plans, such as HMO's, that sacrifice desirable opportunities for individual choice of other kinds. Perhaps the best that can be hoped for is that individual fee-for-service practitioners will eventually be allowed to contract with patients for liability regimes comparable to those that their HMO competitors have been able to adopt in a competitive market with limited judicial oversight. ${ }^{88}$

Another regrettable consequence of a legal rule barring contractual limitations of tort rights in particular bargaining circumstances might be to deprive some patients of appropriate care altogether. In a few places-such as rural North Carolina and Molokai, Hawaii-increases in liability insurance premiums have recently caused general practitioners to forego delivering babies, forcing patients to travel long distances for obstetrical services. If private agreements limiting tort rights are unenforceable if entered into by individual patients lacking the alternative of receiving care under customary rules, a possible solution to this problem is precluded. Perhaps an innovative insurer will offer a policy permitting a physician to offer a patient the option of retaining her full tort rights by paying an additional fee equal to the insurer's estimate of the risk. ${ }^{89}$ In the absence of such insurance, however, the consequence of the law's consumer protection effort is clearly

86. If patients vary in their propensity to sue and thus in the value they place on their tort rights, those providers who are forced by law to offer their services without limiting their liability exposure will attract those patients who are most likely to sue. The resulting higher insurance costs, once reflected in fees, will drive away those patients who place a lower value on full tort rights and presumably are less likely to invoke them. Such adverse selection would be destructive of fee-forservice practice.

87. See infra note 91 , describing the problems associated with collective choice.

88. A possible danger is the use of standard-form contracts by community practitioners. Thus, should a local medical society propose such a contract, consumers might find it difficult to locate a physician willing to serve them on other terms. Antitrust law would govern any agreement to adopt a uniform contract, even one purporting to be a desirable reform. Cf. Paramount Famous Lasky Corp. v. United States, 282 U.S. 30 (1930) (an agreement by film distributors to contract for the exhibition of films only on the condition that every exhibitor accept the arbitration provisions of the standard exhibition contract, whereby arbitration and arbitration awards were enforced by the collective action of these distributors, constituted a conspiracy in restraint of trade).

89. This example also illustrates the possible consequences of another judicially created safeguard. If the mother cannot by contract bind her expected offspring to a different set of legal rights, the baby's health will be jeopardized by the mother's inability to receive care. On this issue, see Doyle v. Giuliucci, 401 P.2d 1, 43 Cal. Rptr. 697 (1965) (holding child bound by arbitration clause); Atiyah, supra note 47 , at 295 . 
undesirable. The courts must be aware of the possible destructiveness of good intentions.

\section{$\mathrm{V}$ \\ Conclusion: Consumer Choice Versus Professional Monopoly}

The proposal to encourage privately negotiated malpractice reforms provides an excellent occasion for comparing the changing conceptual foundations of public policy toward the health care industry with the premises of malpractice law itself. ${ }^{90}$ Although the ideological underpinnings of the old health care system are rapidly giving way, they still support some relics of the old monolithic edifice. In particular, some features of malpractice law-such as its faith in professional custom as a benchmark for judging professional performance, its exclusion of efficiency considerations, and its assumption that the legal system must define all rights and duties-distinctly manifest the old paradigm of a centrally regulated health care system supplying a uniform product.

It is a striking irony that the discomfiture of the medical profession under the present tort system results in significant part from the law's incorporation of the profession's own premises about the nature of health care and the patient's entitlement. This article has shown how changing premises of health policy and changing practices of buyers and sellers of health services are invalidating some basic assumptions of tort doctrine. In particular, it is no longer necessary-and indeed it is destructive-for the law aggressively to oppose contractual modifications of tort rights. Although courts should continue to ensure that bargains are struck under conditions conducive to informed and meaningful choice, they should also be cognizant of the substantial benefits that consumers may gain from private reforms of tort rules. Critics who fear the consequences of letting consumers fend for themselves in the health care marketplace should be reassured by the continued presence of limited judicial oversight.

In the larger health care marketplace, consumer choice is proving a useful corrective for professional dominance and for physicians' myopic tendency to focus on the presumed benefits of their services, to underweigh costs and other side effects of their ministrations, and to undervalue alternatives such as prepaid group practice, contract practice, and prevention. Just as consumer choice has undermined the tyranny of the old health care system's traditional values and standards, the health care industry's new competitiveness offers consumers opportunities to bypass the legal system's monopoly over the

90. Professor Atiyah's critique in this symposium, supra note 47, of the proposal to encourage private reform reveals sharply how one's conception of health care as a centrally defined entitlement produced by a unitary delivery system influences one's judgment on the proper source and mutability of tort rules. Contrary to Professor Atiyah's suggestion that my advocacy of contractual tort reforms is aimed at bringing about a privatization of doctor/patient relationships, id. at 293-94, the argument here is that such privatization has already occurred and that the time has come for the law to accommodate itself to demonstrable changes in national health policy and in the marketplace itself. 
costly business of making and administering rules for allocating the risk of iatrogenic injury. The proposal to let consumers select in the marketplace the rules they wish to govern medical injuries can be viewed as a challenge to lawyers' professional dominance analogous to that which consumer choice has lately mounted against professional hegemony in the medical field. Similarly, the legal system's predictable resistance to consumer choice can be seen as a manifestation of the same kind of professional distrust of consumer sovereignty that physicians have long displayed. It would be ironic, indeed, if the medical profession were to be victimized by inescapable tort rules prescribed by a legal monopoly strongly analogous to the medical monopoly that for so long denied people meaningful choices with respect to professional services.

In the final analysis, it is necessary to appeal to the good will and democratic values of the legal system to obtain the needed enlargement of the realm of consumer choice in this area and to prevent the preclusion of change by any means other than the political and judicial processes. Not only would reform through consumer choice take pressure for law reform off the political system, but it would permit desirable experimentation and the optimal satisfaction of differing consumer needs and preferences. It remains, of course, an open question whether this path to tort reform would be much traveled even if it were clearly open for traffic. ${ }^{91}$ Nevertheless, it is not implausible that, once this option becomes recognizably available, ${ }^{92}$ consumers will gradually come to realize that voluntary modifications of their

91. The education of consumers in this area could be a slow process, requiring as it does instillation of an appreciation that the rights to be surrendered are of limited value and that the potential cost savings to be realized, while not large for any individual, are worth obtaining. The educational problem may be exacerbated in the context of collective choices made in the employment setting. Because of the unlikelihood that any one individual's "vote" will determine the group decision, no individual has much incentive to inform himself of the merits of the choice being made. See generally M. Olson, The Logic of Collective Action (1971). Similarly, if employers or union leaders perceive that a reform will be misinterpreted by the mass of uninformed workers as a retraction rather than a conferral of benefits, they will pass up the opportunity to effectuate it. An HMO may likewise fear that any effort on its part to change liability rules will be misconstrued by consumers.

The alternative to collective choice is individual choice, allowing a consumer a discount if he waives particular rights. In these circumstances, the consumer's incentive to inform himself is increased (though the discount may still not be enough to induce him to master the complexities of the subject). The most promising model is perhaps an employer-negotiated option for individuals to choose care from a single provider with or without his full tort rights. Such options might be tendered together with disinterested advice on the advantages and disadvantages of each.

Whether liability insurers will pass on to providers savings proportional to their success in negotiating waivers of tort rights with their patients is another problematic question. See Note, Customizing Liability Rules in the Federal Employees Health Benefits Program, LAw \& Contemp. ProBs., Spring 1986, at 238-39. Unless they do, of course, the cost savings and thus the incentive to change approaches would be minimal, except for self-insured providers.

Despite these reasons for doubting that private reforms will soon or ever be forthcoming in the real world, it still seems desirable for the legal system to make room for them. It is generally desirable to let individuals benefit from economizing choices. In time, consumers may learn where their true interests lie and become less enamored of a legal system that ostentatiously holds out "rights" while systematically hiding the price tag.

92. It is a fair observation that, because the law has not definitively blocked private reforms in the past, the lack of initiatives may signify a lack of interest on the part of consumers. See Atiyah, 
tort rights can serve their interest in obtaining good health care and financial security at a reasonable cost. changes in the legal climate will in time elicit any interest in privately negotiated cort reforms. 